О.М. Охотнікова', Т.П. Іванова', О.А. Ошлянська', О.В. Поночевна', О.І. Усова', О.В. Шарікадзе ${ }^{1}$, Н.Ю. Яковлева', Т.М. Ткачова', О.М. Грищенко ${ }^{2}$, О.Ф. Зарудня², Р.В. Мостовенко², Н.Б. Погодаєва

\title{
Клінічний протокол
}

медичної допомоги дітям із коронавірусною інфекцією (COVID-19), яка перебігає на фоні хронічних соматичних захворювань

Національна медична академія післядипломної освіти імені П.Л. Шупика, м. Київ, Україна ${ }^{2}$ Національна дитяча спеціалізована лікарня «ОХМАТДИТ», м. Київ, Україна

Modern Pediatrics. Ukraine. 4(108): 18-32. doi 10.15574/SP.2020.108.18

For citation: Okhotnikova OM, Ivanova TP, Oshlyanskaya OA, Ponochevnaya OV et al. (2020). Treatment protocol of coronavirus infection (COVID-19) in children with chronic somatic diseases. Modern Pediatrics. Ukraine. 4(108): 18-32. doi 10.15574/SP.2020.108.18

У рамках протоколу узагальнено клінічні рекомендації щодо діагностики і лікування дітей з коронавірусною інфекцією COVID-19, яка перебігає на тлі різних хронічних соматичних захворювань. В основу протоколу покладено матеріали багатьох іноземних рекомендаційних документів, а також останнього вітчизняного протоколу щодо виявлення терапії коронавірусної інфекції, яка викликана COVID-19 (наказ M03 України від 20.05 .2020 № 1227). Відображено аспекти класифікації ступеня тяжкості і факторів ризику тяжкого перебігу хвороби, до яких належать і фонові хронічні соматичні захворювання, що потребує індивідуалізованого підходу до лікування. Охарактеризовано діагностичні критерії цієї інсекції, а також відмінності клінічної симптоматики COVID-19 у дітей від клінічних проявів у дорослих. Окремо наведено дані про ускладнення дитячої інфекції COVID19 - мультисистемний запальний синдром. Особливість протоколу - рекомендації щодо ведення дітей з інфекцією COVID-19, яка перебігає на фроні хвороб серцево-судинної системи (вроджених вад серця, порушень серцевого ритму і провідності, легеневої гіпертензії тощо), захворювань органів дихання (бронхіальної астми і бронхолегеневої дисплазії), ревматичних (ювенільних артритів, системних хвороб сполучної тканини і системних васкулітів з ураженням легень, варіантів хвороб, які потребують постійної терапії глюкокортикоїдами або перебігають на тлі цукрового діабету) та інших аутоімунних захворювань (аутоімунного гепатиту, гломерулонефриту, особливо з хронічною недостатністю фрункції печінки або нирок). Також наведено рекомендації щодо ведення дітей, в яких COVID-19 розвинулася на фоні хвороб нирок і сечовидільної системи, ендокринних захворювань (цукрового діабету I типу, патології щитоподібної залози та наднирників), хвороб онкологічного і гематологічного генезу, у тому числі в стані імуносупресії.

Ключові слова: COVID-19-інфекція, діагностика, фонові хронічні соматичні захворювання, лікування, діти.

\section{Treatment protocol of coronavirus infection (COVID-19) in children with chronic somatic diseases}

O.M. Okhotnikova' ${ }^{1}$ T.P. Ivanova' ${ }^{2}$, O.A. Oshlyanskaya' ${ }^{1}$, O.V. Ponochevnaya' ${ }^{1}$, O.I. Usova' ${ }^{1}$, O.V. Sharikadze',

N.Yu. Yakovleva ${ }^{1}$, T.M. Tkacheva', O.M. Grishchenko' , O.F. Zarudnaya ${ }^{2}$, R.V. Mostovenko ${ }^{2}$, N.L. Pogodaeva ${ }^{2}$

'Shupyk National Medical Academy of Postgraduate Education, Kyiv, Ukraine

${ }^{2}$ National Children's Specialized Hospital «OKHMATDET», Kyiv, Ukraine

The article summarizes the clinical recommendations for the diagnosis and treatment of children with coronavirus infection COVID-19, which occurs against a background of various chronic somatic diseases. This protocol is based on the materials of many international reference documents, as well as the latest Ukrainian protocol for the detection and treatment of coronavirus infection COVID-19 (Order No. 1227 of 05.20.2020). Aspects of the classification of severity and risk factors for the severe course of the disease are reflected, which include background somatic diseases requiring an individualized approach to treatment. The diagnostic criteria for this infection are characterized, as well as the differences in the clinical symptoms of COVID-19 in children and the clinical manifestations in adults. Separately, data are presented on the complication of childhood COVID-19 infection, a multisystemic inflammatory syndrome. The peculiarity of this protocol is recommendations for the management of children with COVID-19 infection, which occurs against a background of diseases of the cardiovascular system (congenital heart defects, pulmonary hypertension, cardiac arrhythmias and conduction disorders, etc.), respiratory diseases (bronchial asthma and bronchopulmonary dysplasia), rheumatic (juvenile arthritis, connective tissue diseases and systemic vasculitis with lung damage, variants of diseases requiring constant glucocorticoid therapy or occurring in the presence of diabetes mellitus) and other autoimmune diseases (autoimmune hepatitis, glomerulonephritis, especially with chronic liver or kidney failure). Recommendations are also given for the management of children with COVID-19 concurrently with diseases of the kidneys and urinary system, endocrine diseases (diabetes mellitus type I, disorders of the thyroid and adrenal glands), oncological and hematological diseases, including the immunosuppression states.

Key words: COVID-19 infection, diagnosis, background chronic somatic diseases, treatment, children.

\footnotetext{
Клинический протокол медицинской помощи детям с коронавирусной инфекцией (COVID-19), протекающей на фоне хронических соматических заболеваний

Е.Н. Охотникова', Т.П. Иванова', Е.А. Ошлянская', Е.В. Поночевная', Е.И. Усова', Е.В. Шарикадзе', Н.Ю. Яковлева',

Т.М. Ткачева', О.Н. Грищенко, О.Ф. Зарудняя', Р.В. Мостовенко ${ }^{2}$, Н.Б. Погодаева

'Национальная медицинская академия последипломного образования имени П.Л. Шупика, г. Киев, Украина

${ }^{2}$ Национальная детская специализированная больница «ОХМАТДЕТ», г. Киев, Украина

B рамках протокола обобщены клинические рекомендации по диагностике и лечению детей с коронавирусной инфекцией COVID-19, протекающей на фоне различных хронических соматических заболеваний. В основе данного протокола лежат материалы многих иностранных рекомендательных документов, а также последнего отечественного протокола по выявлению и терапии коронавирусной инфекции, вызванной штаммом COVID-19 (приказ М3 Украины от 20.05.2020 № 1227). Отражены аспекты классисрикации степени тяжести и фракторов риска тяжелого течения болезни, к которым относятся и фоновые хронические соматические заболевания, требующие индивидуализированного похода к лечению. Охарактеризованы диагностические критерии данной инфекции, а также отличия клинической симптоматики COVID-19 у детей от клинических проявлений у взрослых. Отдельно представлены данные об осложнении детской инфрекции COVID-19 - мультисистемном воспалительном синдроме. Особенность данного протокола - рекомендации по ведению детей с инфекцией COVID-19, протекающей на фоне болезней сердечно-сосудистой системы (врожденных пороков сердца, легочной гипертензии, нарушений сердечного ритма и проводимости и др.), заболеваний органов дыхания (бронхиальной астмы и бронхолегочной дисплазии), ревматических (ювенильных артритов, системных болезней соединительной ткани и системных васкулитов с
} 
поражением легких, вариантов болезней, требующих постоянной глюкокортикоидной терапии или протекающих на фоне сахарного диабета) и других аутоиммунных заболеваний (аутоиммунного гепатита, гломерулонефрита, особенно с хронической недостаточностью фрункции печени или почек). Даны также рекомендации по ведению детей, у которых COVID-19 развилась на фоне болезней почек и мочевыделительной системы, эндокринных заболеваний (сахарного диабета I типа, патологии щитовидной железы и надпочечников), болезней онкологического и гематологического генеза, в том числе в состоянии иммуносупрессии.

Ключевые слова: COVID-19-инфекция, диагностика, фоновые хронические соматические заболевания, лечение, дети.

\section{Діагноз: Коронавірусна хвороба (COVID-19, 2019-nCoV, U07.1)}

Нормативні посилання:

1. Протокол «Надання медичної допомоги для лікування коронавірусної хвороби (COVID-19)» від 01.04.2020 відповідно до Закону України від 30.03.2020 № 539-IX «Про внесення змін до деяких законів України щодо забезпечення лікування коронавірусної хвороби (COVID-19)».

2. COVID-19 - guidance for paediatric services Last modified, Royal College of Paediatrics and Child Health, 30 March 2020.

3. Стандарти медичної допомоги «Коронавірусна хвороба (COVID-19)» (наказ МОЗ України від 28.03.2020 № 722).

4. Тимчасове керівництво ВООЗ «Глобальне спостереження за інфекцією людини - нового коронавірусу (2019-nCoV)» від 31.01.2020 (WHO / 2019-nCoV / SurveillanceGuidance / 2020.3 Global Surveillance for human infection with novel coronavirus (2019-nCoV) Interim guidance v3 31 January 2020 [Електронний ресурс]. - Режим доступу: https://www.who.int/ publications-detail/global-surveillance-for-human-infection-with-novel-coronavirus-(2019-ncov) та інших міжнародних документів.

5. Зміни до Стандартів медичної допомоги «Коронавірусна хвороба (COVID-19)» (наказ МОЗ України від 20.05.2020 № 1227).

Мета протоколу: покращення якості надання медичної допомоги хворим дітям із фоновою хронічною соматичною та інфекційною патологією, асоційованою 3 підтвердженою коронавірусною хворобою середньотяжкого, тяжкого і критичного перебігу (через реалізацію порядку діагностики, призначення і застосування медикаментів для лікування коронавірусної інфекції (SARS-nCov-19).

Дата розробки: квітень-травень 2020 року, дата оновлення: червень 2020 року.

Розробники: заступник головного лікаря з медичної роботи канд. мед. наук Т.П. Іванова; зав. кафедри педіатрії № 1 НМАПО імені П.Л. Шупика проф. О.М. Охотнікова; зав. інфекційнобоксованого відділення дітей молодшого віку О.Ф. Зарудня; зав. педіатричного відділення О.М. Грищенко; зав. інфекційно-боксованого діагностичного відділення канд. мед. наук Р.В. Мостовенко; доцент кафедри педіатрії № 1 НМАПО імені П.Л. Шупика О.І. Усова, О.В. Поночевна, лікарі-ординатори відділення.

При госпіталізації здійснюються обстеження для оцінки клінічного стану пацієнта, проведення диференційної діагностики та визначення можливості застосування зазначених у протоколі лікарських засобів з огляду на наявність протипоказань і взаємодію лікарських засобів (табл. 1).

Необхідні заходи щодо оцінки клінічного стану пацієнта і перебігу фонового захворювання

Таблиия 1 та визначення функціонального стану органів і систем

\begin{tabular}{|c|c|c|c|}
\hline Положення & $\begin{array}{l}\text { Необхідні дії відповідно } \\
\text { до клінічного протоколу }\end{array}$ & Виконавці & $\begin{array}{c}\text { Індикатори якості } \\
\text { медичної допомоги }\end{array}$ \\
\hline $\begin{array}{l}\text { Організація надання лікувально- } \\
\text { діагностичної допомоги } \\
\text { Шифр за МKX-10: } \\
\text { Коронавірусна інфекція } \\
\text { - U07.1 - COVID-19, що підтвер- } \\
\text { джено лабораторним досліджен- } \\
\text { ням; } \\
\text { - U 07.2 - COVID-19, що відпові- } \\
\text { дає клінічним або епідеміологіч- } \\
\text { ним даним, коли лабораторне } \\
\text { дослідження є незавершеним або } \\
\text { недоступним }\end{array}$ & $\begin{array}{l}\text { Обов'язкові: } \\
\text { - збір скарг та анамнезу; } \\
\text { - клінічний огляд; } \\
\text { - гемограма (розгорнутий за- } \\
\text { гальний аналіз крові); } \\
\text { - біохімічний аналіз крові (глюко- } \\
\text { за, креатинін, білірубін!); } \\
\text { - рентгенографія та КТ ОГК! } \\
\text { - ЕКГ, Ехо-КГ; } \\
\text { - ПЛР; } \\
\text { - УЗД ОЧП; } \\
\text { - імунологічне дослідження; } \\
\text { - потова проба за показаннями; } \\
\text { - ФЕГДС за показаннями } \\
\text { - пульсоксиметрія; } \\
\text { - консультація суміжних спеціалі- } \\
\text { стів за показаннями }\end{array}$ & $\begin{array}{l}\text { НДСЛ «ОХМАТДИТ» } \\
\text { Інфекційно-боксоване відділення } \\
\text { для дітей молодшого віку: } \\
\text { зав. відділення } \\
\text { Зарудня О.Ф., } \\
\text { лікарі відділення. } \\
\text { Інфрекційно-боксоване діагностич- } \\
\text { не відділення: } \\
\text { зав. відділення Мостовенко Р.В., } \\
\text { лікарі відділення. } \\
\text { Педіатричне відділення: } \\
\text { зав. відділення Грищенко О.М., } \\
\text { лікарі відділення }\end{array}$ & $\begin{array}{l}\text { Своєчасне встановлення клініч- } \\
\text { ного діагнозу, визначення ступе- } \\
\text { ня тяжкості процесу протягом } \\
\text { 1-2-3 днів. } \\
\text { Своєчасне встановлення основ- } \\
\text { ного фонового захворювання. } \\
\text { Своєчасне призначення відповід- } \\
\text { ного лікування з урахуванням } \\
\text { потреб терапії фонової патології } \\
\text { та її тяжкості, а також можливої } \\
\text { взаємодії між лікарськими засо- } \\
\text { бами основного захворювання та } \\
\text { коронавірусної інфекції }\end{array}$ \\
\hline
\end{tabular}


Коронавірусна хвороба 2019 (COVID-19) - захворювання, що викликається новим PHК-вмісним коронавірусом SARS-CoV-2, визначення статусу якої та необхідний обсяг обстеження для цього наведено в таблицях 2 і 3.

Визначення випадків для COVID-19 (за ВоОз)

\begin{tabular}{|c|c|}
\hline $\begin{array}{l}\text { Варіанти } \\
\text { випадків }\end{array}$ & Характеристика випадків захворювання \\
\hline $\begin{array}{c}\text { Випадок } \\
\text { підозри на } \\
\text { захворювання }\end{array}$ & $\begin{array}{l}\text { А. Пацієнт із гострим респіраторним захворюванням (лихоманка та принаймні один симптом - кашель } \\
\text { або задишка), а також історія подорожі чи проживання в місцевості, де було повідомлено про передачу хворо- } \\
\text { би COVID-19 в суспільстві за } 14 \text { днів до появи симптомів. } \\
\text { АБО } \\
\text { В. Пацієнт із будь-яким гострим респіраторним захворюванням ТА контакт із підтвердженим або ймовірним } \\
\text { випадком COVID-19 протягом останніх } 14 \text { днів до появи симптомів. } \\
\text { АБО } \\
\text { С. Пацієнт із тяжким гострим респіраторним захворюванням (лихоманка та принаймні один симптом - } \\
\text { кашель або задишка ТА потреба в госпіталізації), а ТАКОЖ за відсутності альтернативного діагнозу, який } \\
\text { повністю пояснює клінічну картину }\end{array}$ \\
\hline $\begin{array}{c}\text { Вірогідний } \\
\text { випадок }\end{array}$ & $\begin{array}{l}\text { А. Випадок підозри, щодо якого результат тестування на вірус є непереконливим. } \\
\text { АБО } \\
\text { В. Випадок підозри, щодо якого тестування не проведене з будь-яких причин }\end{array}$ \\
\hline $\begin{array}{l}\text { Підтвердже- } \\
\text { ний випадок }\end{array}$ & Людина з лабораторно підтвердженою інфекцією COVID-19 незалежно від клінічних ознак та симптомів \\
\hline $\begin{array}{c}\text { Визначення } \\
\text { контакту }\end{array}$ & $\begin{array}{l}\text { Особа, яка відповідає одному із зазначених випадків контакту протягом 2-14 днів від появи симптомів } \\
\text { у особи з вірогідним або підтвердженим випадком: } \\
\text { 1. Контакт віч-на-віч з особою з вірогідним або підтвердженим випадком на дистанції } 1 \text { метр або понад } 15 \text { хв. } \\
\text { 2. Прямий фрізичний контакт із вірогідним або підтвердженим випадком. } \\
\text { 3. Безпосередній нагляд за хворим із вірогідною або підтвердженою інфрекцією COVID-19 без застосування } \\
\text { належних засобів індивідуального захисту. } \\
\text { 4. Інші ситуації, визначені на основі локальної оцінки ризиків }\end{array}$ \\
\hline
\end{tabular}

Необхідні обстеження дітей з підозрюваним / підтвердженим COVID-19

Таблиия 3

\begin{tabular}{|c|c|}
\hline Варіант обстеження & Складові обстеження \\
\hline & Початкові діагностичні тести \\
\hline $\begin{array}{l}\text { Загальний аналіз } \\
\text { крові / біохімічний } \\
\text { аналіз крові }\end{array}$ & $\begin{array}{l}\text { Клінічний аналіз крові, сечовина та електроліти, печінкові проби, СРБ, тропонін, фреритин, } \\
\text { лактатдегідрогеназа, панель згортання і д-димер. } \\
\text { •Якщо розглядається питання щодо імуномодулюючої терапії, необхідне визначення також інтерлейкіну-6 }\end{array}$ \\
\hline $\begin{array}{l}\text { Мікробіологічні } \\
\text { дослідження }\end{array}$ & $\begin{array}{l}\text { Мікробіологічний посів змивів, крові та сечі. } \\
\text { `Тестування на ВІЛ має проводитися у всіх дітей, в яких розглядається лікування лопінавіром / } \\
\text { ритонавіром, але в очікуванні результатів не слід відкладати лікування }\end{array}$ \\
\hline $\begin{array}{l}\text { Радіологічні } \\
\text { дослідження }\end{array}$ & Рентгенографрія органів грудної клітки. За показаннями: КТ, МРТ ОГК \\
\hline Інші & Exo-KГ \\
\hline & Пропоновані поточні тести моніторингу (при погіршенні стану пацієнта) \\
\hline $\begin{array}{l}\text { Загальний аналіз } \\
\text { крові / біохімічний } \\
\text { аналіз крові }\end{array}$ & $\begin{array}{l}\text { Клінічний аналіз крові, сечовина та електроліти, печінкові проби, } \\
\text { СРБ, фреритин, УЗД }\end{array}$ \\
\hline
\end{tabular}

\section{Діагностичні критерії коронавірусної інфекції COVID-19}

\section{Особливості COVID-19 у дітей:}

- Діти хворіють рідше і легше (40\% без фебрильної лихоманки).

- У дітей частіше реєструються ко-інфекції (передусім грип А, грип В, аденовірусна, риновірусна, бокавірусна та респіраторно-синцитіальна вірусна інфекція тощо).

- Рівень прокальцитоніну в дітей підвищується набагато частіше, ніж у дорослих (тому після встановлення діагнозу COVID-19 призначення антибіотиків виправдане з перших днів хвороби, особливо в пацієнтів ранньої вікової групи).

- У дітей частіше виникають шлунково-кишкові симптоми порівняно з дорослими. У більшості дітей із SARS-CoV-2 спостерігалася лихоманка, але це не відноситься до інших нових CoVs. Випадки інфекції, викликані MERS-CoV, часто перебігають безсимптомно.

- Більш високий ризик тяжких форм інфекції, викликаної SARS-CoV-2, як і інших коронавірусних інфекцій, може спостерігатися в дітей раннього віку та в тих, які мають супутню патологію (наприклад, вроджені вади розвитку), а також у разі вірусних ко-інфекцій. 
Особливості клінічної картини коронавірусних інфекцій у дітей (за результатами аналізу сезонних коронавірусних інфекцій) характеризуються ураженням як верхніх (ринофарингіт, тонзиліт), так і нижніх дихальних шляхів (бронхіт, бронхіоліт) та альвеол (пневмонія). Клінічної різниці при інфікуванні тим чи іншим штамом сезонного коронавірусу не встановлено. Моноінфекція частіше перебігає у вигляді легкого або середньотяжкого ураження верхніх відділів дихальних шляхів, може розвиватися ко-інфекція з іншими респіраторними вірусами (респіраторно-синцитіальним вірусом, риновірусом, бокавірусом, аденовірусом), що обтяжує перебіг захворювання і призводить до ураження нижніх відділів респіраторного тракту (пневмонія, бронхіоліт).

\section{Основні діагностичні критерії:}

\section{I. Клінічні критеріi:}

- основні скарги: підвищення температури тіла, нежить, біль у горлі, сухий кашель, зниження нюху;

- клінічні синдроми:

- лихоманка від субфебрильної (при захворюваннях легкого ступеня тяжкості) до фебрильної (при тяжкому ступені хвороби і при поєднаних інфекціях);

- катаральний синдром: кашель, ринорея, гіперемія мигдаликів, задньої стінки глотки;

- респіраторний синдром проявляється задишкою, зниженням сатурації крові киснем ( $\mathrm{SatO}_{2}$ ), тахікардією, ознаками дихальної недостатності (ціаноз, участь допоміжних м'язів в акті дихання, втягнення міжреберних проміжків); бронхіт і пневмонія розвиваються частіше при поєднанні коронавірусної інфекції з іншими респіраторними вірусами (риновірусом, PC-вірусом), характеризуються відповідними перкуторними та аускультативними проявами;

- можливий абдомінальний синдром (нудота, блювання, біль у животі) i/або діарейний синдром, який нерідко проявляється в дітей при респіраторних інфекціях у перші 5-6 діб, у тому числі при інфекціях, викликаних SARS-CoV i MERS-CoV.

SARS-асоційована коронавірусна інфекція має більш легкий клінічний перебіг і сприятливий наслідок у дітей віком до 12 років порівняно з підлітками і дорослими пацієнтами, але може ускладнюватися так званим «мультисистемним запальним синдромом у дітей, асоційованим з COVID-19», який дуже схожий за клінічною симптоматикою на хворобу Кавасакі системний безрецидивний васкуліт та інфекційно-токсичний шок.

Мультисистемний запальний синдром у дітей (multisystem inflammatory syndrome in children, MIS-C; раніше - pediatric multisystem inflammatory syndrome, PMIS) - це нове, рідкісне, загрозливе для життя захворювання, пов'язане з COVID-19, розвитком порушень серцевої діяльності та функції інших органів. Вікова частота MIS-C: до 4 років - 35\%, 5-9 років 25\%, 10-14 років - 24\%, 15-21 рік - 16\%. У більшості дітей віком до 21 року (частіше від 2 до 16 років) клінічна симптоматика у вигляді температури тіла $\geq 38^{\circ} \mathrm{C}$ упродовж декількох (2-3) днів виникає одночасно з іншими симптомами:

- роздратованість, збудження або кволість, знижена активність дитини;

- немотивований біль у животі, втрата апетиту;

- діарея;

- блювання;

- висип;

- двобічний кон'юнктивіт;

- гіперемовані губи з тріщинами і / або

• гіперемований бугристий язик, що нагадує малину або полуницю;

- набряк кистей і стоп, які можуть мати ціанотично-гіперемований колір (як при обмороженні);

- задишка може бути в разі системного ураження легень, але частіше за рахунок кардіоваскулярної патології;

- систолічна дисфункція лівого шлуночка в поєднанні з низьким систолічним тиском;

- потреба в штучній вентиляції легень і значно рідше - в екстракорпоральній мембранній оксигенації (ЕКМО) протягом 3-6 днів.

Спеціалісти Центру з контролю і профілактики захворювань США (CDC) виділили такі крuтеріï MIS-C: 
- Лихоманка ( $\geq 38^{\circ} \mathrm{C}$ протягом $>24$ год), лабораторно підтверджені ознаки запалення, свідчення тяжкого перебігу захворювання із залученням декількох органів і систем $(>2)$ та необхідність госпіталізації.

- Відсутність інших можливих варіантів діагнозу.

- Наявний або нещодавній ПЛР-позитивний результат на SARS-CoV-2, позитивний серологічний тест або тест на виявлення антитіл до COVID-19; або контакт із хворим на COVID-19 у період 4 тижнів до виникнення симптомів.

- Будь-який випадок смерті дитини зі свідченнями щодо інфекції SARS-CoV-2 слід розглядати як можливо перенесений MIS-C.

II. Фактори ризику тяжкого перебігу хвороби в дітей незалежно від різновиду коронавірусу, насамперед наявність у дитини несприятливого преморбідного фону:

1) хронічні захворювання органів дихання:
a) хронічні захворювання легень;
b) муковісцидоз зі значним респіраторним дефіцитом;
c) інтерстиціальні хвороби легень;
d) бронхіальна астма тяжкого ступеня;
е) нейрогенні респіраторні ускладнення.

2) Імуноскомпроментовані стани різного генезу (захворювання або лікування, при яких у 1,5 раза частіше відзначаються пневмонії, частіше хворіють діти віком від 5 років):

а) лікування злоякісного новоутворення;

b) *первинний імунодефіцит;

c) ** застосування імуносупресивних препаратів, включаючи тривале (>28 днів поспіль) щоденне лікування глюкокортикостероїдами;

d) пацієнти після трансплантації (органів або стовбурових клітин);

е) аспленія (функціональна або хірургічна, включає серпоподібні клітинні хвороби).

* Первинний імунодефіцит:

• комбінований імунодефіцит;

- лімфопенія CD4 (кількість CD4<200×106/л) у контексті будь-якого іншого імунодефіциту, у т.ч. ВІЛ-інфекції;

- будь-який первинний імунодефіцит (потребує лікування профілактичними антибіотиками або імуноглобуліном) та застосування імуносупресивних препаратів.

** До імуносупресивних препаратів належать: азатіоприн, лефлуномід, метотрексат, мікофенолат (мікофенолат мофетил або мікофенолова кислота), циклоспорин, циклофосфамід, такролімус, сиролімус. Ці засоби НЕ містять гідроксихлорохін або сульфасалазин окремо або в комбінаціі. Біологічні / моноколональні препарати включають ритуксимаб протягом останніх 12 місяців; інгібітори фактора некрозу пухлин (етанерцепт, адалімумаб, інфліксимаб, голімумаб, цертолізумаб та біоподібні варіанти всіх перелічених); тоцилізумаб; абатацепт; белімумаб; анакінра; сейкінумаб; іксекізумаб; устекінумаб; сарилумумаб; канакінумаб. Невеликі молекули включають інгібітори JАК (інгібітори кінази Януса) - барацитиніб, тофацитиніб тощо.

3) Гемодинамічно значущі вади розвитку і / або вади розвитку серця за ціанотичним типом.

4) Діти першого року життя.

5) Ко-інфекція з респіраторно-синцитіальна вірусною інфекцією.

III. Анамнестичні епідеміологічні критерії:

- наявність закордонних поїздок за 14 днів до появи перших симптомів хвороби;

- наявність тісних контактів за останні 14 днів з особами, в яких є підозра на COVID-19 або з особами, в яких діагноз SARS-nCov-2 підтверджено лабораторно.

IV. Допоміжні критерії:

1) радіологіині критеріӥ: COVID-19 викликає гостру тяжку форму вірусної пневмонії, тому променева діагностика дуже важлива, оскільки КТ ОГК може бути першим дослідженням, що вказує на ознаки вірусного ураження легень, дає змогу оцінити його тяжкість і несприятливі прогностичні ознаки подальшого розвитку.

a) первинним КТ-патерном COVID-19 є картина інфільтрації окремих вторинних легеневих часточок за типом «матового скла» (симптом «сухого листя») з подальшим зменшенням об'єму ураження при сприятливому розвитку подій або їх наростанні, приєднанні КТ-картини «бруків- 
ки» і появі в зоні «матового скла» альвеолярної інфільтрації при несприятливому варіанті захворювання. Ці симптоми є передвісниками розвитку гострого респіраторного дистрес-синдрому;

b) при пізнішому первинному обстеженні первинними КТ-ознаками є симптом «бруківки» і ділянки альвеолярної інфільтрації, що корелює з несприятливим подальшим перебігом і летальним кінцем;

с) для вірусної пневмонії при COVID-19 характерне розташування змін у задніх субплевральних і перибронхіальних відділах. Порожнини, вузлові утворення, плевральні і перикардіальні випоти і лімфоаденопатія при COVID-19 відсутні;

d) стадійність процесу за часом і формування в частини хворих залишкових змін у легенях, що, як і при гриповій пневмонії H1N1 (2008-2019 pp., 2015-2016 pp.) та атиповій пневмонії SARS-

Диференційна діагностика для встановлення остаточного діагнозу

Таблиия 4

\begin{tabular}{|c|c|c|}
\hline Положення & $\begin{array}{l}\text { Необхідні дії відповідно } \\
\text { до клінічного маршруту }\end{array}$ & Виконавці \\
\hline $\begin{array}{l}\text { У всіх дітей слід передусім виключити інші рес- } \\
\text { піраторні вірусні інфекції, інші хвороби, схожі } \\
\text { за клінічною картиною на COVID-19, зокрема: } \\
\text { грип, парагрип, адено-, рино- і респіраторно- } \\
\text { синцитіальну, метапневмо- і бокавірусні інфек- } \\
\text { ції, мікоплазмову і хламідійну інфекції тощо, } \\
\text { позалікарняну і вірусні пневмонії, гострий та } \\
\text { облітеруючі бронхіоліти, бронхолегеневу дис- } \\
\text { плазію, муковісцидоз, вроджені вади серця, } \\
\text { магістральних судин і легень, вроджені і набуті } \\
\text { (включаючи ВІЛ-інфекцію) імунодесріцити, } \\
\text { інтерстиціальні захворювання легень }\end{array}$ & $\begin{array}{l}\text { Обов'язкові: } \\
\text { - збір скарг та анамнезу; } \\
\text { - клінічний огляд; } \\
\text { - розгорнута гемограма; } \\
\text { - розгорнута урограма; } \\
\text { - біохімічний аналіз крові (глюкоза, білірубін !) ; } \\
\text { - рентгенографія ОГК, КТ ОГК } \\
\text { - ЕКГ, Ехо-КГ; } \\
\text { - ПЛР; } \\
\text { - УЗД ОЧП; } \\
\text { - імунологічне дослідження; } \\
\text { - потова проба; } \\
\text { - ФЕГДС за показаннями; } \\
\text { - пульсоксиметрія }\end{array}$ & $\begin{array}{l}\text { Завідувачі відділень } \\
\text { Зарудня О.Ф., } \\
\text { Грищенко О.М., } \\
\text { Мостовенко Р.В., } \\
\text { лікарі відділення, } \\
\text { суміжні дитячі спеціалісти: } \\
\text { - інфекціоніст, } \\
\text { - торакальний хірург, } \\
\text { - кардіолог, } \\
\text { - генетик, } \\
\text { - радіолог, } \\
\text { - імунолог. } \\
\text { Своєчасне встановлення діагнозу, визначення } \\
\text { ступеня тяжкості процесу протягом 1-2 днів. } \\
\text { Своєчасне встановлення діагнозу фонової } \\
\text { патології за її наявності. Своєчасне призна- } \\
\text { чення відповідного лікування }\end{array}$ \\
\hline $\begin{array}{l}\text { Фібробронхоскопія (за показаннями - } \\
\text { проведення бронхоальвеолярного лаважу і } \\
\text { біопсії слизової оболонки) }\end{array}$ & $\begin{array}{l}\text { Показання до фрібробронхоскопії та дослі- } \\
\text { дження бронхоальвеолярної рідини, біопсії: } \\
\text { Діти з підозрою на інфекційний процес: } \\
\text { - бактеріологічне дослідження на мікросрло- } \\
\text { ру та її чутливість до антибіотиків; } \\
\text { - вірус-цитологічні тести } \\
\text { усі пацієнти: } \\
\text { - лейкоцитограма; } \\
\text { - пошук гемосидеринвмісних макрофрагів для } \\
\text { виключення синдрому альвеолярної кровотечі; } \\
\text { - пошук РАS-позитивного гранулярного } \\
\text { матеріалу в клітинах для виключення аль- } \\
\text { веолярного протеїнозу (мутації дисфункції } \\
\text { сурфактанту або порушення GM-CSF); } \\
\text { - пошук інтрацитоплазматичних тілець із пен- } \\
\text { таломінованими включеннями (електронна } \\
\text { мікроскопія), позитивних CD-1а лімфоцитів } \\
\text { (для виключення легеневого гістіоцитозу) }\end{array}$ & $\begin{array}{l}\text { Лікарі відділення функціональної } \\
\text { діагностики }\end{array}$ \\
\hline $\begin{array}{l}\text { За можливості проводяться дослідження } \\
\text { вентиляційної функції (дихальні } \\
\text { функціональні тести) }\end{array}$ & $\begin{array}{l}3 \text { метою уточнення тяжкості і глибини } \\
\text { функціональних порушень }\end{array}$ & $\begin{array}{l}\text { Бактеріологічна лабораторія, } \\
\text { патоморфологічне відділення, } \\
\text { медико-генетичне відділення }\end{array}$ \\
\hline $\begin{array}{l}\text { Для дітей з дитячими інтерстиціальними } \\
\text { легеневими хворобами (Child's Interstitial } \\
\text { Lung Disease - chlLDs), в яких інші діагно- } \\
\text { стичні дослідження не дали змоги встанови- } \\
\text { ти точний діагноз chlLDs, або у разі ургентної } \\
\text { ситуації - потрібна термінова діагностика; } \\
\text { рекомендується хірургічна біопсія легень }\end{array}$ & $\begin{array}{l}\text { Пацієнтам із chlLDs, які потребують біопсії } \\
\text { легень, рекомендується виконання її під кон- } \\
\text { тролем відеоторакоскопії (сильна рекомен- } \\
\text { дація) }\end{array}$ & Медико-генетичне відділення \\
\hline $\begin{array}{l}\text { Для новонароджених із chlLDs і тяжкою фор- } \\
\text { мою захворювання зі швидким прогресуван- } \\
\text { ням або при позитивному сімейному анамне- } \\
\text { зі щодо інтерстиціальних захворювань легень } \\
\text { у дітей рекомендується генетичне тестування } \\
\text { для виявлення генетичних дефектів }\end{array}$ & $\begin{array}{l}\text { 1) Для новонароджених виключити мутації в } \\
\text { генах білків сурфактанту SFTPB, SFTPC, } \\
\text { АВСАЗ. } \\
\text { 2) Для новонароджених із chlLDs та вродже- } \\
\text { ним гіпотиреозом рекомендується тестуван- } \\
\text { ня на NKX2.1 мутації або делеції (тиреоїд- } \\
\text { транскрипційний фактор TTF). } \\
\text { 3) Для новонароджених із chlLDs та рефрак- } \\
\text { терним легеневим гістіоцитозом рекомендуєть- } \\
\text { ся тестування на FOXF1 делецію або мутацію. } \\
\text { 4) Для дітей, які пережили неонатальний } \\
\text { період і мають сhlLDs, рекомендується тесту- } \\
\text { вання на SFTPC I ABCA3 мутації. } \\
\text { 5) Для дітей віком від } 1 \text { місяця з chILDs і клі- } \\
\text { нічною симптоматикою гіпотиреозу, негатив- } \\
\text { ними результатами тестів на ABCA3 і SFTPC, } \\
\text { рекомендується тестування на NKX2.1 } \\
\text { (TTF-1) мутації або делеції }\end{array}$ & Медико-генетичне відділення \\
\hline
\end{tabular}


CoV-1 (2003 р.), розглядаються як ранні ознаки розвитку прогресуючого легеневого фіброзу, тому необхідне часте (кожні 4 дні) проведення КТ для своєчасної оцінки динаміки процесу, появи ранніх ознак фіброзу легень і змін лікувальної тактики;

е) оцінювати результати радіологічних досліджень повинні мінімум два рентгенологи, які мають досвід роботи в торакальній радіології, із залученням третього незалежного експерта, якщо висновки радіологів різняться;

f) інформативність традиційної рентгенографії в оцінці вірусного ураження легень низька, більш клінічно значущою є КТ як більш чутливий метод виявлення ранніх змін. Однак в умовах реанімаційного відділення при оцінці динаміки легеневого процесу роль традиційної рентгенографії є безсумнівною.

У разі необхідності для встановлення остаточного діагнозу в дитини проводиться диференційна діагностика (табл. 4).

Терапевтичний алгоритм власне коронавірусної хвороби COVID-19 у дітей залежно від ступеня іiї тяжкості наведено в таблиці 5.

Ведення дітей з мультисистемним запальним синдромом

- Постільний режим, достатнє за калорійністю харчування та адекватна гідратація.

- Контроль електролітного балансу і гомеостазу.

- Моніторинг вітальних функцій і сатурації кисню.

- Контроль за прохідністю респіраторного тракту, за показаннями виняткових оксигенотерапія, яку за наявності ознак гіпоксії розпочати негайно через назальний зонд або маску. Високопоточна оксигенотерапія, неінвазивна або інвазивна механічна вентиляція виняткових за показаннями, примусова штучна вентиляція легень - у виняткових випадках.

- Контрольні аналізи крові та сечі (СРБ, електроліти, печінкові і міокардіальні ферменти, ниркові показники, коагулограма).

- Аналіз газового складу крові і повторна рентгенографія легень за показаннями.

Фармакотерапія:

- Противірусні лікарські засоби: отримано ефект у тяжких випадках тільки від застосування ремдезивіру, проте в дітей його дози не визначено; комбінація лопінавіру / ритонавіру виявилася неефективною.

- Гідроксихлорохін у поєднанні з азитроміцином не підтвердили позитивного ефекту, більш того, їх застосування супроводжувалося наростанням серцевої недостатності, можливо, обумовленим побічним ефектом азитроміцину подовжувати інтервал QT, тому з останніх рекомендацій ці препарати видалено.

• Арбідол та препарати інтерферону не довели своєї ефективності та безпеки.

Лікування дітей з коронавірусною хворобою COVID-19

Таблиия 5

\begin{tabular}{|c|c|c|}
\hline Характеристика ступеня тяжкості захворювання & Група дітей & Варіанти та обсяг лікування \\
\hline $\begin{array}{l}\text { Легкий та середньотяжкий ступінь хвороби } \\
\text { Рівень оксигенації не порушений. } \\
\text { Інфекція верхніх дихальних шляхів легкого ступеня тяжкості }\end{array}$ & Усі групи & $\begin{array}{l}\text { Підтримувальна терапія. } \\
\text { Доцільність лікування противірусними препаратами має } \\
\text { розглядатися в кожному випадку індивідуально }\end{array}$ \\
\hline $\begin{array}{l}\text { Тяжкий ступінь захворювання } \\
\text { Легкий - помірний респіраторний дистрес-синдром*: } \\
\text { 1) Невентиляційний тип, що потребує } \mathrm{FiO}_{2} \text { (фрракція кисню } \\
\text { на вдиху) >40\% для підтримки насичення } 88-97 \% \text {. } \\
\text { 2) Вентиляційний: } \\
\text { - індекс оксигенації - відношення парціального напруження } \\
\text { кисню в артеріальній крові до фракції кисню у вдихуваному } \\
\text { газі, слугує для оцінки функції обміну кисню в легенях: } 4 \leq 16 \text {; } \\
\text { - індекс насичення киснем (киснева сатурація) - відсоток } \\
\text { окисленого гемоглобіну відносно загального вмісту гемо- } \\
\text { глобіну у крові: } 5 \leq 12,3\end{array}$ & Група ризику* & $\begin{array}{l}\text { Підтримувальна терапія. } \\
\text { Лікування противірусними препаратами має розглядатися } \\
\text { в кожному випадку індивідуально }\end{array}$ \\
\hline $\begin{array}{l}\text { Критичний ступінь захворювання } \\
\text { Тяжкий респіраторний дистрес-синдром **: } \\
\text { - індекс оксигенації: } \geq 16 ; \\
\text { - індекс насичення киснем: } \geq 12,3 \\
\text { Септичний шок. } \\
\text { Порушення свідомості. } \\
\text { Поліорганна недостатність }\end{array}$ & Усі групи & $\begin{array}{l}\text { Підтримувальна терапія. } \\
\text { Розглядається необхідність противірусної терапії }\end{array}$ \\
\hline
\end{tabular}

Примітки: * Групи ризику. Діти групи ризику мають аналізуватися окремо, як особливий ризик клінічного погіршення, а рішення щодо призначення антивірусної або імуномодулюючої терапії повинно враховувати усі можливі ризики.

** Респіраторний дистрес-синдром, визначений критеріями PARD: Pediatric Acute Lung Injury Consensus Conference Group (Pediatric acute respiratory distress syndrome: consensus recommendations from the Pediatric Acute Lung Injury Consensus Conference. Pediatr Crit Care Med. 2015 Jun; 16 (5): 428-439). 
- Слід уникати невиправданого використання антибіотиків, особливо широкого спектра дії. Необхідний моніторинг стану дитини з ко-інфекцією, ознаками приєднання бактеріальної або грибкової інфекції, що є показанням для призначення відповідних антибактеріальних і протигрибкових препаратів.

- Глюкокортикостероїди призначаються при тяжкому ступені системної запальної відповіді та задишки (з або без ознак респіраторного дистрес-синдрому), змінах радіологічної картини в легенях. Застосовуються коротким курсом на 3-5 днів, дозування за метилпреднізолоном не більше 1-2 мг/кг/добу.

- Препарати імуноглобуліну показані в імуносупресивній дозі 2 г/кг маси тіла за 2-3 дні.

- Препарати гепарину показані дітям з ознаками порушень згортання крові, схильністю до розвитку тромбозів під контролем коагулограми.

- Симптоматична терапія, активне запобігання та лікування ускладнень, вторинної інфекції, підтримка функціонування усіх органів і систем.

- Респіраторна підтримка: неінвазивна або інвазивна (тільки якщо життєзберігаюча) вентиляція легень, за неефективності - ЕКМО.

- Підтримка циркуляції: контролювати об'єм рідин, що вводяться, поліпшення мікроциркуляції, вазоактивні препарати і моніторинг гемодинаміки - за потреби.

- Психотерапія: діти і підлітки уразливі до розвитку синдрому посттравматичного стресу. Психологічне консультування необхідне для якнайшвидшого одужання. Для дітей більш старших вікових груп, особливо з проявами фобій, тривожності, психологічних розладів показана активна психологічна підтримка і лікування.

Загальні принципи лікування дітей з COVID-19, яка перебігає на фоні хронічних хвороб

- Дотримання основних принципів, що стосуються способу життя дитини і викладені в чинних рекомендаціях.

- Планове відвідування медичних закладів, соціальних структур або планову госпіталізацію під час пандемії COVID-19 доцільно відкласти.

- Проведення планової вакцинації і санації порожнини рота є недоцільним через високий ризик контамінації COVID-19 у медичних закладах.

- Хворим, які перебувають на диспансерному обліку з інвалідизуючого захворювання, для яких характерна декомпенсація (хронічна серцева недостатність, цукровий діабет, онкологічні і гематологічні захворювання, ревматологічна патологія, ниркова недостатність, діаліз тощо, діти після трансплантаціі), має бути забезпечена можливість телефонного контакту з лікуючим лікарем-спеціалістом організації, до якої вони прикріплені.

- При синдромі лихоманки необхідна термометрія кожні 3 год із веденням щоденника, щоденний контроль об'єму випитої і виділеної рідини та маси тіла пацієнта (зважування в стандартних умовах натще).

- Парацетамол є жарознижувальним препаратом вибору в дозі 10-15 мг/кг (не більше 60 мг/добу). Не рекомендовано використання ацетилсаліцилової кислоти для купування лихоманки, однак слід продовжувати ї̈ застосування, якщо препарат був призначений раніше в якості антиагрегантної терапії.

- Діти, які застосовували постійну терапію при хронічній патології, у тому числі глюкокортикостероїди або інші препарати з пригніченням імунітету, не повинні переривати лікування, якщо інше не рекомендовано лікарем.

Показання до госпіталізації:

- тяжка клінічна картина захворювання і нетиповий перебіг гострих респіраторних вірусних інфекцій (ГРВІ) та грипу, позалікарняної пневмонії;

- діти з групи ризику тяжкого перебігу COVID-19.

\section{1. Ведення COVID-19 у дітей із захворюваннями серцево-судинної системи}

У теперішній час немає досліджень, в яких були б описані діти з патологією серцево-судинної системи і COVID-19, а тому й вплив вірусу на цю когорту пацієнтів остаточно не з'ясований.

До групи ризику тяжкого перебігу респіраторних інфекцій, зокрема COVID-19, входять діти з такою патологією серцево-судинної системи: 
- єдиний шлуночок (із синдромом гіпоплазії лівих відділів серця, атрезією легеневої артерії, атрезією трикуспідального клапана, подвійним відходженням магістральних судин від правого шлуночка, або пацієнти, які перенесли операцію Норвуда, Блелок-Тауссіг (БТ), Гленна або Фонтена);

- легенева гіпертензія;

- захворювання серця, ускладнені серцевою недостатністю II-IV ФК та злоякісними аритміями, при яких постійно застосовується медикаментозна терапія;

- вроджені вади серця з необхідністю кардіохірургічного лікування в найкоротший термін (наростання недостатності кровообігу на фоні максимально можливої медикаментозної терапіi), а також 3 місяці після корекції вродженої вади серця;

- синдром гетеротаксії. Гетеротаксія - правобічна або лівобічна транспозиція органів грудної i/або черевної порожнини, включає в себе багато різноманітних порушень, оскільки існує багато варіантів правого / лівого поворотів. Гетеротаксія може бути повною (situs inversus totalis або situs inversus, коли усі внутрішні органи, розташовані зазвичай праворуч, за такої патології розміщені ліворуч і навпаки) або частковою (неповний situs inversus, коли обмежена кількість органів мають транспозицію або situs inversus ambiguous, коли латеральний орган розташований по центру). Частота усіх дефектів латералізації становить приблизно 1:15 000;

- перебіг хвороби Кавасакі, що потребує застосування імуносупресивних препаратів;

- діти після трансплантації серця.

Пацієнти, які раніше перенесли операцію на серці з позитивними результатами, не застосовують жодних лікарських засобів і відносяться до I-II групи здоров'я, а також не належать до вищезазначених категорій високого ризику, мають виконувати основні рекомендації з профілактики.

Особливості діагностики і лікування:

- при об'єктивному огляді, зокрема, оцінці ступеня дихальної недостатності та визначенні тяжкості перебігу COVID-19 (задишка, ціаноз, SatO2 тощо), необхідно враховувати особливості соматичного статусу, характерного для основного захворювання серцево-судинної системи (зокрема «сині» вроджені вади розвитку серця, висока легенева гіпертензія, термінальна хронічна серцева недостатність тощо).

- при визначенні рівня маркерів міокардіоцитолізу слід враховувати, що при гострому ушкодженні міокарда значно підвищуються рівні тропоніну I (білок регуляції м'язового скорочення), міокардіальної фракції загальної креатинфосфокінази (КФК-МВ), міоглобіну, АСТ (до 8-10 норм). Натрій-уретичні пептиди BNP або NT-proBNP (антагоністи ренін-ангіотензинальдостеронової системи) є біомаркерами міокардіального стресу, що дають змогу об'єктивно діагностувати дисфункцію міокарда з високою аналітичною чутливістю і специфічністю, які часто підвищуються в дітей з тяжкими респіраторними захворюваннями. Клінічна значущість цих змін не з'ясована.

- Необхідний моніторинг показників коагулограми в дітей, які застосовують антикоагулянтну терапію за основним захворюванням, відповідно до чинних рекомендацій, і перехід на більш частий моніторинг у разі розвитку синдрому дисемінованого згортання крові.

- Обов'язкове проведення ЕКГ та Ехо-КГ при госпіталізації до стаціонару усім дітям із патологією серцево-судинної системи.

- На сьогодні немає доказів щодо ризиків застосування інгібіторів ангіотензин-перетворюючого ферменту (АПФ) та блокаторів рецепторів ангіотензину II (БРА) при інфікуванні SARS$\mathrm{CoV}-2$, через що відміна базової фармакотерапії (iАПФ/БРА в поєднанні з бета-блокаторами, антагоністами мінералокортикоїдних рецепторів і діуретиками за потреби) у хворого зі стабільною серцевою недостатністю або в пацієнта з легкими формами COVID-19 (без ураження легень) є необгрунтованою, а при розвитку пневмонії, асоційованої з інфекцією SARS $\mathrm{CoV}-2$, терапія іАПФ/БРА може бути тимчасово припинена.

1а. Особливості ведення пацієнтів із вродженими вадами серия та магістральних судин

- За наявності показань до хірургічної корекції тієї чи іншої вади у випадках, підозрілих на COVID-19, або наявності підтвердженої інфекції, операція проводиться тільки за життєвими показаннями з дотриманням усіх правил транспортування дитини, забезпечення анестезіологічного супроводу, ізоляції в післяопераційному періоді, а також заходів щодо захисту персоналу. 
- При стабільному стані планове оперативне лікування рекомендовано відкласти до закінчення дії карантинних заходів із продовженням консервативного лікування.

- Принципи терапії серцевої недостатності аналогічні вищеописаним.

1b. Особливості ведення пацієнтів із порушеннями ритму та провідності серия

- Підходи до невідкладної терапії при тахі- і брадиаритміях у дітей з COVID-19 не відрізняються від загальноприйнятих, зокрема, немає даних про вищий ризик ураження легень на фоні терапії аміодароном.

- Діти зі спадковими аритмічними синдромами та COVID-19 мають підвищений проаритмічний ризик.

- Пацієнтам із синдромом Бругада показане більш активне лікування лихоманки.

- Пацієнтам із синдромом подовженого інтервалу QT у разі застосування препаратів, які збільшують інтервал QT (зі списком препаратів можна ознайомитися на сайті www.crediblemeds.org), показаний контроль ЕКГ до призначення лікування антивірусними препаратами (лопінавіром, ритонавіром, ремдизивіром), антибактеріальними препаратами (азитроміцином), хлорохіном / гідроксихлорохіном і моніторинг ЕКГ на тлі такого лікування.

- У пацієнтів із підтвердженою / підозрюваною інфекцією COVID-19 рекомендується відкласти усі планові інтервенційні втручання, у тому числі катетерні аблації тахіаритмій та імплантації пристроїв корекції порушень провідності.

- За наявності екстрених і життєвих показань інтервенційні / хірургічні аритмологічні втручання доцільно здійснювати після оцінки ризику і потенційних переваг втручання.

- На час пандемії COVID-19 планові візити пацієнтів для оцінки і корекції роботи імплантованих пристроїв доцільно перенести. Контроль роботи імплантованих пристроїв за можливості здійснювати за допомогою засобів дистанційного моніторингу.

\section{2. Ведення COVID-19 у дітей із захворюваннями дихальної системи}

При безсимптомній або легкій формі захворювання в дітей з бронхолегеневою патологією лікування вдома під контролем спеціаліста можливе в разі дотримання усіх рекомендацій і режиму ізоляції.

- Бронхіальна астма в дітей $\boldsymbol{i}$ COVID-19. Діти з бронхіальною астмою, які отримують базову терапію, ïi не припиняють при появі респіраторної симптоматики. Погіршення стану і поява ознак дихальної недостатності потребують термінової госпіталізації і продовження лікування в стаціонарі. На сьогодні існує припущення, що інгаляційна глюкокортикостероїдна терапія в поєднанні з пролонгованими бета-2-адреноміметиками ( $\beta 2$-агоністами) чинять позитивний вплив на перебіг коронавірусної інфекції не тільки в дітей з астмою, але й у хворих без астми.

- Дітям із туберкульозом органів дихання, які отримують основний курс терапії, протитуберкульозні препарати не відміняються. Симптоматична терапія призначається відповідно до загальних рекомендацій. Призначення противірусної та антибактеріальної терапії вирішується індивідуально з урахуванням стану дитини.

- Діти з хронічними і вродженими бронхолегеневими захворюваннями (вади розвитку легень, первинна циліарна дискінезія, муковісцидоз, бронхоектази після перенесених гострих захворювань тощо) продовжують базову терапію при появі респіраторної симптоматики. Особливістю проведення в таких дітей інгаляційної терапії за допомогою небулайзера є застосування фільтра на видиху для попередження інфікування повітря приміщення і ретельна дезінфекція застосованого обладнання. У дітей з муковісцидозом слід обов'язково враховувати флору, що висівається з дихальних шляхів до появи гострого захворювання.

За наявності даних про висівання Pseudomonas aeruginosa, Burkholderia cepacia і метицилін-резистентного золотистого стафілококу (MRSA), у разі появи симптомів гострого респіраторного захворювання, обов'язково застосовуються антибактеріальні препарати з урахуванням чутливості флори, що висівається.

- Діти з бронхолегеневою дисплазією (БЛД) належать до групи високого ризику з тяжкого перебігу ГРВI (особливо викликаних респіраторно-синцитіальним i риновірусом) мають ризик смерті внаслідок респіраторних ускладнень і потребують обов'язкової госпіталізації. Частина дітей з БЛД мають ускладнення у вигляді хронічної дихальної недостатності, на фоні якої при ГРВІ може розвиватися гостра дихальна недостатність, через що пацієнтам із тяжкою і середньотяжкою формами БЛД має проводитися ретельний моніторинг рівня $\mathrm{SatO}_{2}$ за перших ознак будь-якої ГРВІ, з урахуванням вихідних показників сатурації. Діти, в яких була 
припинена киснева терапія, в період вірусної інфекції знову можуть відчувати гіпоксію і потребують кисневої підтримки. Передбачається, що пацієнти з БЛД можуть мати більш тяжкий перебіг COVID-19, особливо при ко-інфекції.

\section{3. Ведення COVID-19 у дітей з ревматичними та аутоімунними захворюваннями}

Групи ризику щодо тяжкого перебігу COVID-19 інфекції в дітей з цією патологією:

- ювенільний артрит із системним початком, особливо за наявності в анамнезі епізодів синдрому активації макрофагів;

- системні захворювання сполучної тканини, особливо такі як системний червоний вовчак, системна склеродермія, які мають інтерстиціальне легеневе ураження;

- будь-які інші ревматичні захворювання, що мають легеневе ураження, такі як АНЦА-асоційовані васкуліти;

- ревматичні захворювання в дітей, які отримують постійну глюкокортикостероїдну терапію;

- ревматичні захворювання в поєднанні з коморбідною патологією, такі як цукровий діабет, а також ревматичні хвороби, що проявляються органними ураженнями (аутоімунний гепатит, гломерулонефрит), особливо за наявності ознак хронічної недостатності органів, як то хронічна хвороба нирок, хронічна печінкова недостатність.

Рекомендащї з лікування дітей з ревматичними захворюваннями:

1. Діти з ревматичними хворобами в період пандемії COVID-19 не повинні припиняти планову терапію, призначену лікуючим ревматологом.

2. Доцільно мінімізувати контакти, відмовитися від планових візитів до ревматолога, планових заборів аналізів крові, якщо це не обговорено з лікуючим ревматологом. Пріоритет - за дистанційним обслуговуванням пацієнтів.

3. Дітям, які отримують планову глюкокортикостероїдну терапію та знаходяться в стані ремісії, доцільно обговорити з лікуючим ревматологом можливість подальшого зниження дози глюкокортикостероїдів, якщо це не нашкодить пацієнту.

4. Дітям, які отримують планову імуносупресивну терапію ритуксимабом при стабільному стані, слід обговорити з ревматологом можливість повторних курсів препарату в більш пізній термін, коли ризики інфікування будуть менші.

5. Діти, які знаходяться на замісній терапії внутрішньовенними імуноглобулінами, повинні іiі продовжувати, оскільки це можливий профілактичний захід при розвитку COVID-19-інфекції.

6. При тяжких варіантах перебігу інфекційного процесу, у тому числі викликаного COVID-19інфекцією, розглянути терапію високодозним внутрішньовенним імуноглобуліном разом з поточними національними рекомендаціями, як можливу опцію в дітей, які отримують імуносупресивну терапію і не відповідають на терапію, що проводиться.

\section{4. Ведення COVID-19 у дітей із захворюваннями нирок і сечовидільної системи}

Передбачувана реалізація залучення нирок у патологічний процес при COVID-19 - це розвиток інтерстиціального нефриту, клінічна картина якого визначається інфекцією. Поки збережені ниркові функції, діагноз часто не встановлюється.

Симптоми цих форм неспецифічні:

- ранній початок - у 3-4 роки, а у 30\% - уже на першому році життя;

- інтоксикація;

- біль у животі та / або попереку;

- випадкова знахідка сечового синдрому - гематурія з протеїнурією та абактеріальною лейкоцитурією.

До групи ризику тяжкого перебігу COVID-19 входять діти з такими захворюваннями нирок і сечовидільної системи, при яких доцільна госпіталізація до стаціонару:

- гломерулонефрити, при яких застосовуються глюкокортикостероїди, цитостатична терапія;

- хромосомні і спадкові захворювання, синдроми з ураженням нирок;

- тубулопатії;

- рефлюкс-нефропатія;

- хронічна ниркова недостатність (замісна терапія - гемодіаліз, перитонеальний діаліз, трансплантована нирка). 
Принципи терапії загальні, з урахуванням нефротоксичності препаратів. Терапія основного захворювання не відміняється, дози глюкокортикостероїдів і цитостатичної терапії корегуються лікуючим лікарем, в якого дитина перебуває на диспансерному обліку.

\section{5. Ведення COVID-19 у дітей і підлітків із захворюваннями ендокринної системи}

- При хворобах щитоподібної залози без порушення функції у разі діагностики COVID-19 тактика спостереження змінюється. При тиреотоксикозі і застосуванні тиростатиків, враховуючи потенціальну гепатотропну дію деяких препаратів, рекомендованих при COVID-19, слід ретельніше моніторувати функції печінки. При гіпотиреозі і замісній терапії левотироксином показаний контроль рівня тиреотропного гормону при середньотяжкому і тяжкому перебігу COVID-19.

- При гіпокортицизмі наднирників та приєднанні гострого захворювання існують стандартні рекомендації щодо підвищення дози глюкокортикостероїдів. Оскільки на сьогодні не описано особливостей захворювання при поєднанні гіпокортицизму і COVID-19, рекомендуються дії відповідно до протоколу при гіпокортицизмі, зокрема, призначення стрес-доз глюкокортикостероїдів при ризику кризи гострої наднирникової недостатності (лихоманка $\geq 38^{\circ} \mathrm{C}$, дегідратація, травма, екстрене оперативне втручання). Доза глюкокортикостероїдів може бути підвищена в 2-5 разів залежно від значущості стресу, а при блюванні, циркуляторних порушеннях рекомендується парентеральне введення.

\section{6. Ведення COVID-19 у дітей $\boldsymbol{i}$ підлітків із иукровим діабетом I типу}

Діти з иукровим діабетом (ЦД) 1 типу входять до групи підвищеного ризику тяжкого перебігу COVID-19.

Необхідні визначення та обстеження:

- оцінка епідеміологічного анамнезу;

- наявність симптомів інфекції респіраторного тракту, діареї, втрати маси тіла, блювання, запаху ацетону у видихуваному повітрі, патологічного типу дихання, дегідратації, циркуляторних розладів, підвищення температури тіла. Моніторинг глікемії слід проводити частіше, ніж зазвичай (до 10 і більше разів на добу), визначити наявність і рівень кетонів крові або сечі. Такі симптоми, як задишка і слабкість, часто маскують кетоацидоз, тому діагноз пневмонії слід встановлювати за сукупністю клініко-лабораторних даних і результату КТ легень.

Лікування:

- Важливо не припиняти введення інсуліну; при лихоманці та інтоксикації доза інсуліну може бути підвищена і перерозподілена за рахунок збільшення інсуліну короткої дії. Цільова глікемія 4-10 ммоль/л; рівень кетонів крові не має перевищувати 0,6 ммоль/л. Враховуючи підвищений ризик інфекційних захворювань при ЦД 1 типу в цілому, ISPAD рекомендує обмежити контакти дитини з ЦД 1 типу, забезпечити дистанційне навчання і консультування спеціалістами та обмеження показань до госпіталізації.

- Госпіталізація показана при симптомах кетоацидозу, гіперглікемії >14 ммоль/л, яка супроводжується підвищенням кетонів крові >1,5 ммоль/л, кетонурією, незважаючи на адекватну інсулінотерапію і гідратацію, а також при показаннях для госпіталізації при COVID-19. Діти з поєднанням ЦД 1 типу і COVID-19 мають бути госпіталізовані до інфекційних відділень стаціонарів, в яких є можливість організувати консультативну допомогу дитячого ендокринолога, включаючи технології телемедицини. При Цд 1 типу в дітей може розвинутися кетоацидоз, гіпоглікемія, а також приєднання вторинної бактеріальної інфекції.

- Використання з метою лікування COVID-19 противірусних препаратів лопінавіру / ритонавіру може мати гіперглікемічний ефект і знизити чутливість до інсуліну, що потребує підвищення дози інсуліну. Також слід зазначити, що противірусні препарати, гідроксихлорохін, а також рекомендований при тяжких формах препарат тоцилізумаб в якості небажаних побічних ефектів мають гепатотоксичність, що може потенціювати страждання печінки при ЦД 1 типу і вимагає індивідуального рішення щодо призначення в кожному випадку з наступним моніторингом функцій печінки.

- Діти з ЦД 1 типу мають бути забезпечені витратними матеріалами і медикаментами, засобами для проведення самоконтролю на період ізоляції. Оптимально здійснювати регулярний дистанційний моніторинг дитячим ендокринологом. При погіршенні стану, появі нових і незвичних симптомів рекомендується невідкладна організація телемедичної консультації зі спеціалістами профільного експертного центру. 
7. Ведення COVID-19 у дітей з онкологічними і гематологічними захворюваннями

Превентивні заходи до госпіталізащії:

1. Скринінг кожного пацієнта і членів сім'ї на SARS-CoV-2 до госпіталізації.

2. Діти 3 температурою $>37,3^{\circ} \mathrm{C}$ тривалістю $>3$ днів мають бути госпіталізовані до інфекційного стаціонару для диференційної діагностики.

3. У разі підозри на COVID-19 слід провести КТ легень і ПЛР-діагностику.

4. Ізоляція пацієнта при підозрюваних і підтверджених випадках.

5. При виключенні інфекції можливе продовження протипухлинної терапії.

COVID-19 у дітей з імуносупресією:

- Подовження інтервалу елімінації вірусу (тривале виділення вірусу), збільшення частоти розвитку пневмонії, обструктивних ускладнень, смертності.

- Схильність прогресування інфекції верхніх дихальних шляхів в інфекцію нижніх дихальних шляхів.

- Маніфестація інфекції можлива одразу з розвитку вірусної пневмонії / брохообструктивного синдрому.

- До групи ризику належать діти молодшого віку з основною хворобою легень або інших респіраторних захворювань.

- Розпізнавання факторів ризику для тяжкого респіраторного захворювання дає змогу стратифікувати ступінь тяжкості і своєчасно розпочати лікування (табл. 6).

Рекомендаиї з хіміотерапї:

- Здійснення більш інтенсивного нагляду / лікування дітей з онкологічними захворюваннями; уникати будь-яких можливих переміщень пацієнта з метою зниження ризиків інфікування.

- Індивідуалізація підходу з урахуванням типу онкологічного захворювання, етапу та обсягу протипухлинної терапії.

- Для дітей з нормальним соматичним статусом припустиме продовження хіміотерапії 3 урахуванням основного захворювання та ризиків його прогресування.

- У дітей зі стабільним захворюванням можна розглянути помірну редукцію інтенсивності хіміотерапії або подовження інтервалів між циклами.

- За можливості - рекомендовано проведення терапії за місцем проживання для виключення додаткових ризиків при транспортуванні пацієнтів.

- Трансплантацію та інтенсивну хіміотерапію не слід відкладати, якщо це єдиний захід врятування пацієнта.

Тактика при підтвердженні COVID-19 у період проведення хіміотерапії в дітей:

1. Оцінка ризику прогресування інфекції дихальних шляхів з урахуванням наведених нижче факторів: Т-клітинна лімфопенія, супутні захворювання легень / серця, ко-інфекція.

2. Оцінка ураження серця: міокардит є рідкісною, але серйозною причиною погіршення стану і смерті в пацієнтів із COVID-19; провести необхідні діагностичні дослідження.

3. Дотримування обережності при призначенні інфузійної терапії.

4. Застосовування рекомендацій щодо ведення фебрильної нейтропенії в дітей з онкологічними захворюваннями або ведення лихоманки в дітей з онкологічною патологією без нейтропенії.

3. Припинення імуносупресивної терапії, якщо така терапія зменшує кількість лімфоцитів, поки не настане клінічне поліпшення; контроль вірусного навантаження, вірусного кліренсу.

4. Глюкокортикостероїди - не показані для лікування COVID-19, виключення - життєві показання до застосування за основним захворюванням.

Фактори ризику прогресування тяжких інфекцій нижніх дихальних шляхів (COVID-19)

Таблиия 6 і фактори ризику летальності в дітей з імуносупресією на тлі онкологічних і гематологічних захворювань

\begin{tabular}{|l|l|}
\hline \multicolumn{1}{|c|}{\begin{tabular}{c}
\multicolumn{1}{|c|}{ Фактори ризику прогресування інфекцій } \\
нижніх дихальних шляхів
\end{tabular}} & \multicolumn{1}{c|}{ Фактори ризику летальності } \\
\hline Лімфопенія, інші цитопенії & Застосування стовбурових клітин \\
Вплив легеневих токсинів (тютюнового диму, тотальне & Киснева залежність \\
опромінення тіла у високих дозах) & Терапія високими дозами глюкокортикостероїдів \\
Оцінка за шкалою АРАCHЕ II & Цитопенія \\
Наявність ко-патогенів & Оцінка за шкалою АРACHЕ ॥ \\
Високі дози глюкокортикостероїдів & \\
\hline
\end{tabular}


5. Спектр рекомендованих противірусних препаратів: ремдезивір, нітазоксанід, хлорохін (рекомендації постійно оновлюються).

6. Контроль токсичних ефектів при застосуванні противірусної терапії (табл. 7).

Рекомендації щодо променевої терапї:

- Ризики імуносупресії нижчі, ніж при проведенні системної хіміотерапії.

- Доцільно проведення променевої терапії згідно плану лікування.

- Наступний курс хіміотерапії рекомендовано відкласти.

Рекомендації щодо хірургічного етапу лікування онкологічних хворих:

У разі підозри на COVID-19 або підтвердженої інфекції проводиться тільки за життєвими показаннями з дотриманням усіх правил транспортування пацієнта, забезпечення анестезіологічного супроводу, ізоляції в післяопераційному періоді, а також заходів щодо захисту персоналу.

Таблиия 7

Лікарські засоби, які заборонено або не бажано застосовувати з етіотропною терапією COVID-19'

\begin{tabular}{|c|c|c|c|}
\hline \multirow{2}{*}{$\begin{array}{l}\text { Міжнародна непатентована назва } \\
\text { (МНH) лікарського засобу }\end{array}$} & \multicolumn{3}{|c|}{ Етіотропна терапія COVID-19 } \\
\hline & лопінавір/ритонавір & хлорохін & гідроксихлорохін \\
\hline \multicolumn{4}{|c|}{ Антиретровірусні препарати ${ }^{2}$} \\
\hline Лопінавір/ритонавір & Не можна застосувати & Не бажано & Не бажано \\
\hline Атазанавір & Не можна застосувати & Не бажано & Не бажано \\
\hline Саквінавір & Не можна застосувати & Заборонено & Заборонено \\
\hline Рилпівірин/тенофовір/ емтрицитабін & Не можна застосувати & Заборонено & Заборонено \\
\hline \multicolumn{4}{|l|}{ Антиаритміки } \\
\hline Аміодарон & Заборонено & Заборонено & Заборонено \\
\hline \multicolumn{4}{|c|}{ Антимікробні засоби } \\
\hline Рифампіцин & Заборонено & Заборонено & Заборонено \\
\hline Рифапентин & Не бажано & Заборонено & Заборонено \\
\hline \multicolumn{4}{|c|}{ Дезагреганти } \\
\hline Апіксабан & Заборонено & Не бажано & Не бажано \\
\hline Клопідогрель & Заборонено & Не бажано & Не бажано \\
\hline Ривароксабан & Заборонено & Не бажано & Не бажано \\
\hline Тикагрелор & Заборонено & Не бажано & Не бажано \\
\hline \multicolumn{4}{|c|}{ Антиконвульсанти } \\
\hline Карбамазепін & Не бажано & Заборонено & Заборонено \\
\hline Фенобарбітал & Не бажано & Заборонено & Заборонено \\
\hline Примідон & Не бажано & Заборонено & Заборонено \\
\hline \multicolumn{4}{|c|}{ Антипсихотичні (нейролептики) } \\
\hline Кветіапін & Заборонено & Не бажано & Не бажано \\
\hline Зипрасидон & Заборонено & Заборонено & Заборонено \\
\hline \multicolumn{4}{|c|}{ Снодійні та седативні засоби } \\
\hline Мідазолам & Заборонено & Дозволено & Дозволено \\
\hline \multicolumn{4}{|c|}{ Протиблювотні } \\
\hline Домперидон & Заборонено & Не бажано & Не бажано \\
\hline \multicolumn{4}{|c|}{ Діуретичні калій-зберігаючі засоби } \\
\hline Еплеренон & Заборонено & Дозволено & Дозволено \\
\hline \multicolumn{4}{|c|}{ Антиангінальні засоби } \\
\hline Івабрадин & Заборонено & Не бажано & Не бажано \\
\hline Ранолазин & Заборонено & Не бажано & Не бажано \\
\hline \multicolumn{4}{|c|}{ Гіполіпідемічні засоби } \\
\hline Ловастатин & Заборонено & Дозволено & Дозволено \\
\hline Симвастатин & Заборонено & Дозволено & Дозволено \\
\hline \multicolumn{4}{|c|}{ Імунодепресивні засоби } \\
\hline Сиролімус & Заборонено & Не бажано & Не бажано \\
\hline \multicolumn{4}{|c|}{ Глюкокортикостероїди для місцевого застосування } \\
\hline Будесонід & Заборонено & Дозволено & Дозволено \\
\hline Флутиказон & Заборонено & Дозволено & Дозволено \\
\hline \multicolumn{4}{|c|}{ Глюкокортикостероїди } \\
\hline Тріамсинолон & Заборонено & Дозволено & Дозволено \\
\hline
\end{tabular}

Примітки: Версія 5 (08.04.2020), додаток 5:

1. У таблиці 7 наведено список основних лікарських взаємодій, а 3 повним переліком можна ознайомитися на сайті: https://www.covid19-druginteractions.org.

2. Основні взаємодії хлорохіну і гідроксихлорохіну з антиретровірусними препаратами пов'язані $з$ потенціюванням подовження інтервалу QT і, відповідно, небезпекою фібриляції шлуночків серця, необхідністю частого моніторування ЕКГ у таких хворих.

3. Заборонено - серйозні лікарські взаємодії, які виключають сумісне призначення цих лікарських засобів.

4. Не бажано - потенційні лікарські взаємодії, які потребують спеціального (прискіпливого) моніторування, зміни дозування або часу застосування препаратів. 


\section{REFERENCES/JITEPATУPA}

1. WHO. (2020, February 16-24). Report of the WHO-China Joint Mission on Coronavirus Disease 2019 (COVID-19). [BО03. (2020, Лютий 16-24). Розподіл хворих по важкості стану за даними ВОО3]. URL: $\quad$ who.int/docs/default-source/coronaviruse/who-china-jointmission-on-covid-19-final-report.pdf.

2. Lu X, Zhang L, Du H, Zhang J et al. (2020, April 23). SARS-CoV-2 Infection in Children. N Engl J Med. 382: 1663-1665; published on March 18, 2020, at NEJM.org. [Lu X, Zhang L, Du H, Zhang J та інші. (2020, Квітень 23). Клініко-епідеміологічна характеристика інфекції, викликаної SARS-CoV-2 у дітей. N Engl J Med. 382: 1663-1665, опубліковано 18 березня 2020]. doi: 10.1056/NEJMc2005073.

3. Dong Y, Mo X, Hu Y et al. (2020, June 1). Epidemiology of COVID-19 Among Children in China. Pediatrics. 145 (6). doi: 10.1542/peds.2020-0702.

4. European Centre for Disease Prevention and Control. (2020, March 12) Infection prevention and control for COVID-19 in healthcare settings first update. Technical report. [Технічний звіт щодо заходів інфекційного контролю ECDC]. URL: ecdc.europa.eu/sites/default/files/documents/COVID-19-infection-prevention-and-control-healthcare-settings-march-2020.pdf.

5. WHO. (2019). Coronavirus disease (COVID-19) technical guidance: Infection prevention and control. URL: who.int/emergencies/diseases/novel-coronavirus-2019/technical-guidance/infection-preventionand-control.

6. WHO. (2020, March 20). Global Surveillance for human infection with coronavirus disease (COVID-19). URL: who.int/publicationsdetail/global-surveillance-for-human-infection-with-novel-coronavirus(2019-ncov).

7. ICD-10 Version: 2019. (2019). COVID-19, virus identified. [Кодування згідно Міжнародної класифікації хвороб 10-го перегляду]. URL: icd.who.int/browse10/2019/en\#/U07.1

8. WHO. (2020, May 27). Clinical management of COVID-19. Clinical management of severe acute respiratory infection (SARI) when COVID-19 disease is suspected. Interim guidance on 13 March 2020. [Синдроми, пов'язані з COVID-19 за BOO3]. URL: who.int/publications-detail/clinical-management-of-severe-acute-respiratory-infection-when-novelcoronavirus-(ncov)-infection-is-suspected.

9. Gautret P, Lagier J-C, Parola Ph, Raoult D et al. (2020, March 20) Hydroxychloroquine and azithromycin as a treatment of COVID-19: results of an open-label non-randomized clinical trial. International Journal of Antimicrobial Agents. doi.org/10.1016/j.jjantimicag.2020.105949.

10. Zimmermann P, Nigel C. (2020, May). Coronavirus Infections in Children Including COVID-19. An Overview of the Epidemiology, Clinical Features,
Diagnosis, Treatment and Prevention Options in Children. The Pediatric Infectious Disease Journal. 39 (5): 355-368. Accessed March 12, 2020. doi: 10.1097/INF.0000000000002660..

11. Genentech. (2020, March 18). Genentech Initiates Phase III Clinical Trial Of Actemra In Hospitalized Patients With Severe COVID-19 Pneumonia. URL: https://www.gene.com/media/press-releases/14841/2020-0318/genentech-initiates-phase-iii-clinical-t

12. EAHP. (2020, May). EAHP COVID-19 Resource Centre. [Лікувальні опції, що застосовують в країнах Європи і Світу]. URL: eahp.eu/hp-practice/hospital-pharmacy/eahp-covid-19-resource-centre.

13. Spanish Society of Hospital Pharmacy. (2020, March 19). Hospital pharmacy procedures for the management of antiviral treatment in the new coronavirus sars-cov-2 disease covid-19. URL: eahp.eu/sites/default/files/hospital_pharmacy_procedures_covid-19_march19th.pdf.

14. European Centre for Disease Prevention and Control. (2020). Novel coronavirus (SARS-CoV-2). Technical report. Discharge criteria for confirmed COVID-19 cases - When is i tsafe to discharge COVID-19 cases from the hospital or end home isolation? URL: ecdc.europa.eu/sites/default/files/documents/COVID-19-Discharge-criteria.pdf.

15. Chen Y, Li L. (2020, May). SARS-CoV-2: virus dynamics and host response. The Lancet Infectious Diseases. 20 (5). Published: March 23, 2020. https://doi.org/10.1016/S1473-3099(20)30235-8.

16. WHO. (2019). Country \& Technical Guidance - Coronavirus disease (COVID-19). Laboratory testing for 2019-nCoV in humans. URL: who.int/emergencies/diseases/novel-coronavirus-2019/technicalguidance/laboratory-guidance.

17. Wang XF, Yuan J, Zheng YJ, Chen J, Bao YM, Wang YR, Wang LF, Li H, Zeng JX, Zhang YH, Liu YX, Liu L. (2020, February 17). Retracted: Clinical and Epidemiological Characteristics of 34 Children With 2019 Novel Coronavirus Infection in Shenzhen. 58 (0): 008. doi: 10.3760/cma.j.issn.0578-1310.2020.0008. URL: https://pubmed.ncbi.nlm.nih.gov/32062875/

18. Prise en charge a l'hopital des enfants atteints de COVID-19. (2020, March 31). Recommandations pour le traitement des enfants atteints de COVID-19. Belgian Pediatric Covid-19 Task Force. URL: http://gbsvbs.org/fileadmin/user_upload/Unions/PED/Belg_Recomm_ COVID_ped_31mar_FR.pdf

19. BPAlIG. (2020, April). BPAllG Position Statement: Sars-CoV-2 Treatment Guidance. Position Statement: Management of novel coronavirus (SARS-CoV-2) infection in pediatric patients in the UK and Ireland. URL: https://www.bpaiig.org/sites/ default/files/National_paediatric_COVID19\%20treatment $\%$ 20v1.2_0.pdf 